Bangl. J. Vet. Med. (2008). 6 (2): 185-190

\title{
SERO-SURVEILLANCE AND IMMUNIZATION IN SHEEP AND GOATS AGAINST PESTE DES PETITS RUMINANTS IN BANGLADESH
}

\author{
S. C. Banik, S. C. Podder, M. A. Samad and M. T. Islam \\ Department of Medicine, Faculty of Veterinary Science, Bangladesh Agricultural University, \\ Mymensingh-2202, Bangladesh
}

\begin{abstract}
The sero-surveillance and immunization studies on Peste des Petits Ruminants (PPR) in non-descriptive indigenous sheep and Black Bengal goats aged between 5 to 12 months were carried out in the district of Mymensingh during the period from June to November 2003. Sero-prevalence of PPR by using competitive enzyme linked immunosorbent assay (C-ELISA) was conducted on 100 sheep and 100 goats which were selected randomly from 10 different areas in the district of Mymensingh. Of the 100 sheep and 100 goats tested, $27 \%$ sheep and $25 \%$ goats had positive ( $\geq 50$ ) antibody titre. This indicates that $27 \%$ sheep and $25 \%$ goats might have the capability to resist natural PPR infection and accordingly, sero-monitoring could be required to give a better indication of nation herd immunity. The immunization study against PPR with a commercial PPR $\mathrm{VAC}^{\circledR}$ was conducted on 10 sheep and 10 goats by inoculating @ $1.0 \mathrm{ml}$ vaccine / animal subcutaneously. The clinical, haematological, biochemical and antibody levels were determined at pre-immunization and at $7^{\text {th }}, 14^{\text {th }}$ and $21^{\text {st }}$ day of postimmunization. The mean antibody titre at $7^{\text {th }}, 14^{\text {th }}$ and $21^{\text {st }}$ day of post-immunization in sheep $(38.28 \pm 4.34,58.63 \pm 3.60 \&$ $68.27 \pm 3.09)$ and goats $(49.84 \pm 4.37,63.23 \pm 3.64 \& 76.60 \pm 4.07)$ were significantly $(\mathrm{p}<0.01)$ increased in comparison to the respective pre-immunization mean titre of sheep $(20.0 \pm 6.78)$ and goats $(14.00 \pm 6.96)$. Results of haematological examination showed that the PPR VAC ${ }^{\circledR}$ has no effects on haemoglobin $(\mathrm{Hb})$, erythrocyte sedimentation rate (ESR), packed celled volume (PCV) and total erythrocyte count (TEC). The TLC was markedly increased at all the stages of postimmunization in both sheep and goats but significantly $(\mathrm{p}<0.05)$ increased at $21^{\text {st }}$ day $\left(10.08 \pm 1.5510^{3} / \mathrm{mm}^{3}\right)$ in sheep and at $14^{\text {th }}$ day $\left(14.76 \pm 0.8410^{3} / \mathrm{mm}^{3}\right)$ in goats in comparison to pre-immunization values of sheep $\left(7.95 \pm 0.9710^{3} / \mathrm{mm}^{3}\right)$ and goats $\left(9.00 \pm 1.2810^{3} / \mathrm{mm}^{3}\right)$. No distinct difference was observed on rectal temperature, pulse and respiratory rate between the pre- and post-immunization values which indicates PPR-VAC ${ }^{\circledR}$ has no clinical effects in vaccinated animals. No significant differences on calcium, albumin, total serum protein (TSP) and glucose levels were observed between the pre- and post-immunization values in both the sheep and goats. But the TSP in both the sheep $8.43 \pm 0.69 \mathrm{~g} / \mathrm{dl})$ and goats $(8.26 \pm 0.50$ $\mathrm{g} / \mathrm{dl})$ at $21^{\text {st }}$ day of post-immunization increased insignificantly $(\mathrm{p}>0.05)$ in comparison to the pre-immunization values of sheep $(7.66 \pm 0.79 \mathrm{~g} / \mathrm{dl})$ and goats $(7.89 \pm 0.92 \mathrm{~g} / \mathrm{dl})$. The results of humoral immune response produced by PPR-VAC ${ }^{\circledR}$ indicates the activity of the inoculated vaccine but challenge studies with virulent PPR virus would be required to confirm its efficacy.
\end{abstract}

Key words: PPR, sheep, goats, sero-surveillance, C-ELISA, PPR-VAC ${ }^{\circledR}$, haematology, biochemistry

\section{INTRODUCTION}

Peste des Petits Ruminants (PPR) is the French name of a Rinderpest-like disease in sheep and goats first described in Ivory Coast, West Africa in 1942. Many others prefer the appellation of stomatitis-pneumoniaenteritis complex disease, pseudo-rinderpest of small ruminants and kata. But official instances like FAO and OIE use the French name PPR. It is an acute highly contagious and fatal disease of small ruminants, caused by Morbillivirus close to Rinderpest virus and characterized by fever, necrotic stomatitis, gastro-enteritis and pneumonia. In unprotected animals the morbidity can be up to $100 \%$ and mortality may be 20 to $90 \%$ and in severe outbreaks with $100 \%$ case fatality particularly in goats (Samad, 2008). PPR virus was considered a variant of Rinderpest virus, specially adapted for goats and sheep that had lost its virulence for cattle. It is now known that the two viruses are distinct though closely related antigenically. Goats and sheep are the natural hosts of PPR, but goats appear to be more susceptible and suffer a more severe clinical disease than sheep. In endemic areas, goats more than 4 months up to 24 months age are affected (Samad, 2008). PPR was once thought to be only an African problem, but the recent outbreaks in Middle East and Indian sub-continent causing 
alarming losses of animals especially goats. Outbreaks of PPR are now known to be common in India, Nepal, Bangladesh, Pakistan, Bhutan and Afghanistan. PPR virus first reported in India in 1987 from an outbreak in Tamil Nadu and since then the disease has been reported from all over the country. The outbreaks of a Rinderpest-like disease later confirmed by World Reference Laboratory to be PPR have been occurring in goats since 1993 in Bangladesh (Barrette et al., 1997). The seroprevalence of PPR has been reported to be 36.0\% in sheep, $49.17 \%$ in goats and 19.05\% in cattle from Bangladesh ( Razzaque et al., 2004 ). The outbreaks of PPR caused 74.13\% morbidity and 54.83\% mortality in Black Bengal goats in Bangladesh (Islam et al., 2001, Das et al., 2007). This paper describes the sero-surveillance and effects of immunization in sheep and goats immunized against PPR in Bangladesh.

\section{MATERIALS AND METHODS}

The study on PPR was carried out on sero-surveillance and immunization in sheep and goats during the period from June to November 2003.

\section{Sero-surveillance of PPR}

The sero-surveillance study on PPR was conducted on randomly selected indigenous 100 sheep and 100 Black Bengal goats, of either sex, aged between 5 to 12 months with history of no earlier vaccination against any diseases. These animals were selected from 10 different localities in the district of Mymensingh (Table 1).

\section{Collection of blood}

Blood (about $5.0 \mathrm{ml}$ / animal) was collected from jugular vein of each of the selected 100 goats and 100 sheep in separate sterilized test tubes with and without adding any anti-coagulants. The tubes containing blood without any anti-coagulants were kept in refrigerator overnight and sera were separated as per conventional method by centrifugation at $5000 \mathrm{rpm}$ for 15 minutes. Sera were transferred to the small glass vial and stored at $-20{ }^{\circ} \mathrm{C}$ until tested.

\section{Screening of the sera samples}

Each of the randomly selected sera samples of 100 goats and 100 sheep was screened with the help of commercial competitive enzyme linked immunosorbent assay (C-ELISA) kit (IAEA and BDSL, UK) as described by Sil et al. (2001).

\section{Immunization studies}

Ten non-descriptive indigenous sheep (6 male and 4 females) and 10 Black Bengal goats (6 male and 4 females), aged between 5 to 12 months were purchased from the local market and maintained in the houses of the Bangladesh Agricultural University (BAU) Veterinary Clinic. These experimental animals were allowed to graze day-time in the field and some wheat bran was supplied at night with water supply ad libitum. After acclimatization of these goats in the new environment, parasitological examination of faecal samples, examination of rectal temperature, pulse and respiratory rate, antibody titre against PPR and certain haematobiochemical parameters were determined.

Each of the experimental 10 sheep and 10 goats was immunized with PPR-VAC ${ }^{\circledR}$ (LRI, Mohakhali, Dhaka) @ $1.0 \mathrm{ml}$ / animal subcutaneously. Venous blood from each of the experimental animal was collected in duplicate tubes, one contained double oxalate used for haematology and the other without adding any anti-coagulant used for determination of antibody and biochemical constituents at pre-immunization and at $7^{\text {th }}, 14^{\text {th }}$ and $21^{\text {st }}$ day of post-immunization.

\section{Haematological studies}

Haemoglobin $(\mathrm{Hb})$ concentration (Acid haematin method with Sahli and Hellige hemometer), erythrocyte sedimentation rate (ESR) by using Wintrobe's hematocrit tube, packed cell volume (PCV) by using Wintrobe's hematocrit tube, total erythrocyte count (TEC) by using Thomas's red blood cell pipette with Hayem's solution and total leukocyte count (TLC) by using Thomas's White blood cell pipette with N/10 hydrochloric acid were determined at pre-immunization and at $7^{\text {th }}, 14^{\text {th }}$ and $21^{\text {st }}$ day of post-immunization as described by Samad (2001). 


\section{Antibody determination}

Each serum was subjected to test for PPR antibodies by using C-ELISA test kit as described by Sil et al. (2001).

\section{Biochemical studies}

The biochemical constituents of serum of sheep and goats collected at different stages of immunization were determined with the help of Spectronic ${ }^{\circledR}$ Genesys TM-5 (Spectronic Instrument Inc., Rochester, NY, USA) as per method of the diagnostics kits (Human Gesellschaft fur Biochemica and Diagnostica mbH, Max-PlanckRing 21, D-65205 Wiebaden, Germany).

The serum calcium, serum albumin, total serum protein (TSP) and serum glucose were estimated by using complete test kits Cat No. 10011 at 570 nm, Cat No. 10560 at 546 nm, Cat No. 10570 at 546 nm and Cat No. 10260, 10121 and 10123 at $580 \mathrm{~nm}$, respectively as described by the manufacturer and Diagnostica mbH, Germany ).

\section{Statistical analysis}

Results were analyzed statistically with the help of Student's ‘t’ test for significance as described by Gupta (1982).

\section{RESULTS AND DISCUSSION}

Peste des Petits Ruminants (PPR) is a highly contagious disease affecting small ruminants in African countries situated in a wide-belt between the Sahara and Equator, Middle East and Indian sub-continent (Samad, 2008). Outbreaks of the disease have been reported to be associated with high morbidity and mortality in unprotected goats and the disease is now considered endemic in Bangladesh (Barrette et al., 1997, Islam et al., 2001, Das et al., 2007). Sero-prevalence (Razzaque et al., 2004), evaluation of C-ELISA (Sil et al., 2001), pathological investigation (Khan et al., 2005) and evaluation of antibiotic combined hyperimmune serum therapy (Islam et al., 2003) for PPR infected goats have been reported from Bangladesh. The sero-surveillance and immunization studies in sheep and goats against PPR with a commercial PPR-VAC ${ }^{\circledR}$ would help to assess the feasibility to use vaccine to control PPR in small ruminants under field conditions.

\section{Sero-surveillance}

Sero-prevalence of PPR by using C-ELISA was conducted in non-vaccinated 100 sheep and 100 goats of 10 different areas in the district of Mymensingh. Out of the 100 sheep and 100 goats tested, of which only 27\% sheep and $25 \%$ goats had positive level of PPR antibodies (Table 1). The sero-prevalence results of this study could be compared with earlier findings of Razzaque et al. (2004) who reported sero-prevalence of PPR in 36\% sheep, $49.17 \%$ goats and $19.05 \%$ cattle from the district of Mymensingh. These results indicate that a certain percentage of sheep (27\%) and goats (25\%) in the district of Mymensingh have natural positive level of antibody titre against PPR which might protect against natural PPR challenge, as the humoral antibodies have shown to have a protective value in PPR (Bidjeh et al., 1999, Islam et al., 2003). Maternally derived antibodies against PPR in young animals could be detected up to 6 months of age but fall below the protection threshold level at 3.5 and 4.5 months in lambs and kids, respectively. Therefore, it is suggested that kids and lambs from immunized or exposed dams should be vaccinated at 4 and 5 months of ages, respectively (Awa et al., 2002). Similarly, the antibodies due to naturally exposed to PPR infection might also interfere the efficacy of vaccines. In addition, Anderson and Macky (1994) reported that antibodies against PPR virus and Rinderpest virus are both cross-neutralizing and cross-protective against each other. Accordingly, PPR in small ruminants has primarily been controlled by using tissue culture Rinderpest vaccine in Africa (Taylor 1979, Samad 2008). Therefore, monitoring of antibodies would be required before mass vaccination against PPR, especially in enzootic areas.

\section{Clinical response}

The rectal temperature, pulse and respiratory rates of sheep and goats were recorded at pre-vaccinated and at $7^{\text {th }}, 14^{\text {th }}$ and $21^{\text {st }}$ day of post-vaccinated period and the results are presented in Table 2 . No significant differences were observed on rectal temperature, pulse and respiratory rates between the pre- and post-immunization values. 
Table 1. Sero-surveillance of Peste des Petits Ruminants (PPR) in sheep and goats

\begin{tabular}{|c|c|c|c|c|c|c|c|c|c|c|c|c|}
\hline \multicolumn{2}{|c|}{ S/NArea } & \multirow[t]{2}{*}{ Species } & \multirow{2}{*}{$\begin{array}{l}\text { No. of } \\
\text { animals } \\
\text { tested }\end{array}$} & \multicolumn{8}{|c|}{ No. of animals with antibody titre } & \multirow{2}{*}{$\begin{array}{l}\begin{array}{l}\text { Positive } \\
\text { (titre } \geq 50 \text { ) } \\
\text { No. ( } \%)\end{array}\end{array}$} \\
\hline & & & & $1-10$ & $11-20$ & $21-30$ & $31-40$ & $41-50$ & $51-60$ & $61-70$ & $71-80$ & \\
\hline \multirow[t]{2}{*}{ (1) } & \multirow{2}{*}{ Shesmor } & Sheep & 10 & 4 & 3 & 2 & 1 & 0 & 0 & 0 & 0 & $0(00.00)$ \\
\hline & & Goat & 10 & 3 & 5 & 2 & 0 & 0 & 0 & 0 & 0 & $0(00.00)$ \\
\hline (2) & Digarkanda & Sheep & 10 & 1 & 0 & 1 & 0 & 1 & 2 & 3 & 2 & $7(70.00)$ \\
\hline \multirow[t]{3}{*}{ (3) } & Chatrapur & Sheep & 10 & 0 & 1 & 0 & 1 & 2 & 2 & 3 & 1 & $6(60.00)$ \\
\hline & & Goat & 10 & 0 & 0 & 1 & 2 & 3 & 3 & 1 & 0 & $4(40.00)$ \\
\hline & & Goat & 10 & 1 & 0 & 2 & 1 & 4 & 2 & 0 & 0 & $2(20.00)$ \\
\hline \multirow[t]{2}{*}{ (4) } & Boyra & Sheep & 10 & 2 & 1 & 0 & 3 & 2 & 0 & 2 & 0 & $2(20.00)$ \\
\hline & & Goat & 10 & 0 & 2 & 1 & 2 & 3 & 1 & 1 & 0 & $2(20.00)$ \\
\hline \multirow[t]{2}{*}{ (5) } & Baparipara & Sheep & 10 & 2 & 0 & 1 & 2 & 3 & 1 & 0 & 1 & $2(20.00)$ \\
\hline & & Goat & 10 & 1 & 0 & 1 & 3 & 2 & 2 & 1 & 0 & $3(30.00)$ \\
\hline \multirow[t]{2}{*}{ (6) } & Iswargonj & Sheep & 10 & 0 & 2 & 2 & 3 & 2 & 0 & 1 & 0 & $1(10.00)$ \\
\hline & & Goat & 10 & 1 & 0 & 1 & 2 & 1 & 3 & 2 & 0 & $5(50.00)$ \\
\hline \multirow[t]{2}{*}{ (7) } & Atherobari & Sheep & 10 & 2 & 0 & 1 & 2 & 3 & 1 & 1 & 0 & $2(20.00)$ \\
\hline & & Goat & 10 & 2 & 0 & 0 & 3 & 4 & 1 & 0 & 0 & $1(10.00)$ \\
\hline \multirow[t]{2}{*}{ (8) } & Khalbala & Sheep & 10 & 1 & 1 & 2 & 3 & 1 & 2 & 0 & 0 & $2(20.00)$ \\
\hline & & Goat & 10 & 1 & 0 & 2 & 3 & 2 & 1 & 1 & 0 & $2(20.00)$ \\
\hline \multirow[t]{2}{*}{ (9) } & Shivbari & Sheep & 10 & 0 & 2 & 1 & 2 & 3 & 1 & 1 & 0 & $2(20.00)$ \\
\hline & & Goat & 10 & 1 & 3 & 0 & 2 & 2 & 2 & 0 & 0 & $2(20.00)$ \\
\hline \multirow[t]{2}{*}{ (10) } & Parangonj & Sheep & 10 & 1 & 1 & 0 & 3 & 2 & 1 & 2 & 0 & $3(30.00)$ \\
\hline & & Goat & 10 & 0 & 1 & 2 & 1 & 2 & 3 & 1 & 0 & $4(40.00)$ \\
\hline \multirow{2}{*}{\multicolumn{2}{|c|}{ Total }} & Sheep & 100 & 13 & 11 & 10 & 20 & 19 & 10 & 13 & 4 & $27(27.00)$ \\
\hline & & Goat & 100 & 10 & 11 & 12 & 19 & 23 & 18 & 07 & 0 & $25(25.00)$ \\
\hline
\end{tabular}

\section{Humoral immune response}

The antibody titre against PPR in sheep and goats were determined at pre-immunization and at $7^{\text {th }}, 14^{\text {th }}$ and $21^{\text {st }}$ days of post-immunization and presented in Table 2. The occurrence of low level of natural antibodies against PPR in sheep $(20.0 \pm 6.78)$ and goats $(14.0 \pm 6.96)$ at pre-immunization status indicates that these experimental animals were appropriately selected for immunization study against PPR. The mean antibody titre at $7^{\text {th }}, 14^{\text {th }}$ and $21^{\text {st }}$ day of post-vaccination in sheep were $38.28 \pm 4.34,58.63 \pm 3.60$ and $68.27 \pm 3.09$ and in goats were $49.84 \pm$ 4.37, $63.23 \pm 3.64$ and $76.60 \pm 4.07$, respectively. These findings indicate that the antibody titre in both the sheep and goats at post-immunization increased significantly $(\mathrm{p}<0.01)$ up to the protective level $(\geq 50)$. Although these immunized goats could not be challenged due to lack of virulent challenge PPR virus in the stock. The detection of protective level of antibody against PPR in the PPR-VAC ${ }^{\circledR}$ inoculated sheep and goats indicates that the vaccine has actively stimulated the immune system in the inoculated animals. This findings support the earlier observation of Das et al. (2007) who reported the efficacy of PPR-VAC ${ }^{\circledR}$ against natural PPR infection.

\section{Haematological studies}

To study the haematological effects of PPR-VAC ${ }^{\circledR}$ in the vaccinated small ruminants, haemoglobin (Hb), erythrocyte sedimentation rate (ESR), packed cell volume (PCV), total erythrocyte count (TEC) and total leukocyte count (TLC) were determined at pre-immunization and at $7^{\text {th }}, 14^{\text {th }}$ and $21^{\text {st }}$ day of post-immunization (Table 2). No significant differences between the pre-and post-immunization values of Hb, ESR, PCV and TEC was observed in both the sheep and goats but insignificantly $(\mathrm{p}>0.05)$ increased TLC was observed at $7^{\text {th }}, 14^{\text {th }}$ and $21^{\text {st }}$ day of post-immunization in comparison to pre-immunization values (Table 2). These results indicate that the PPR-VAC ${ }^{\circledR}$ antigen has actively stimulated the leukocytes for the production of humoral immune response. 
Sero-surveillance and immunization against PPR in sheep and goats

Table 2. Clinical and haemato-biochemical responses ( Mean \pm SD) in sheep and goats immunized against PPR

\begin{tabular}{|c|c|c|c|c|c|c|c|}
\hline \multicolumn{2}{|c|}{ S/NParameters } & \multirow[t]{2}{*}{ Species } & \multirow{2}{*}{$\begin{array}{l}\text { No. of } \\
\text { animals } \\
\text { tested }\end{array}$} & \multirow{2}{*}{$\begin{array}{l}\text { Pre- } \\
\text { immuni- } \\
\text { zation }\end{array}$} & \multicolumn{3}{|c|}{ Post-immunization ( days ) } \\
\hline & & & & & 7 & 14 & 21 \\
\hline \multirow[t]{2}{*}{ (1) } & Temperature & Sheep & 10 & $101.90 \pm 0.91$ & $102.39 \pm 0.38$ & $102.18 \pm 0.15$ & $102.76 \pm 1.28$ \\
\hline & $\left({ }^{0} \mathrm{~F}\right)$ & Goat & 10 & $102.13 \pm 0.54$ & $102.46 \pm 0.40$ & $102.36 \pm 0.45$ & $102.58 \pm 0.39$ \\
\hline \multirow[t]{2}{*}{ (2) } & Pulse & Sheep & 10 & $075.60 \pm 3.86$ & $078.60 \pm 4.43$ & $075.60 \pm 3.09$ & $072.00 \pm 1.09$ \\
\hline & (/ minute ) & Goat & 10 & $076.80 \pm 4.73$ & $076.80 \pm 3.79$ & $077.40 \pm 4.42$ & $076.80 \pm 4.73$ \\
\hline \multirow[t]{2}{*}{ (3) } & Respiration & Sheep & 10 & $018.30 \pm 3.30$ & $020.70 \pm 2.31$ & $010.80 \pm 2.15$ & $018.20 \pm 1.99$ \\
\hline & ( / minute ) & Goat & 10 & $026.00 \pm 2.21$ & $027.60 \pm 3.71$ & $028.20 \pm 3.58$ & $027.70 \pm 2.40$ \\
\hline \multirow[t]{2}{*}{ (4) } & Antibody & Sheep & 10 & $020.00 \pm 6.78$ & $038.28 * \pm 4.34$ & $058.63 * \pm 3.60$ & $068.27 * \pm 3.09$ \\
\hline & titre & Goat & 10 & $014.00 \pm 6.96$ & $049.84 * \pm 4.37$ & $063.23^{*} \pm 3.64$ & $076.60 * \pm 4.07$ \\
\hline \multirow[t]{2}{*}{ (5) } & Haemoglobin & Sheep & 10 & $012.52 \pm 1.08$ & $013.06 \pm 1.25$ & $013.33 \pm 1.15$ & $013.46 \pm 1.16$ \\
\hline & ( Hb, g \% ) & Goat & 10 & $012.41 \pm 1.03$ & $012.87 \pm 0.99$ & $013.09 \pm 0.92$ & $013.39 \pm 0.90$ \\
\hline \multirow[t]{2}{*}{ (6) } & $\operatorname{ESR}(\mathrm{mm} /$ & Sheep & 10 & $000.80 \pm 0.26$ & $001.87 \pm 1.31$ & $001.05 \pm 0.25$ & $001.12 \pm 0.29$ \\
\hline & in $1^{\text {st }} \mathrm{hr}$.) & Goat & 10 & $000.75 \pm 0.23$ & $000.90 \pm 0.26$ & $001.02 \pm 0.36$ & $000.95 \pm 0.28$ \\
\hline \multirow[t]{2}{*}{ (7) } & PCV ( \% ) & Sheep & 10 & $032.52 \pm 2.83$ & $033.78 \pm 3.35$ & $033.90 \pm 3.20$ & $032.96 \pm 7.13$ \\
\hline & & Goat & 10 & $024.90 \pm 4.19$ & $026.54 \pm 1.62$ & $026.60 \pm 1.51$ & $026.92 \pm 1.34$ \\
\hline \multirow[t]{2}{*}{ (8) } & TEC $\left(10^{6}\right)$ & Sheep & 10 & $010.04 \pm 1.41$ & $011.25 \pm 1.81$ & $011.72 \pm 1.79$ & $011.95 \pm 1.83$ \\
\hline & $\left.\mathrm{mm}^{3}\right)$ & Goat & 10 & $012.61 \pm 1.45$ & $013.18 \pm 1.14$ & $014.78 \pm 3.46$ & $014.18 \pm 0.98$ \\
\hline \multirow[t]{2}{*}{ (9) } & TLC ( TLC, & Sheep & 10 & $007.95 \pm 0.97$ & $008.77 \pm 1.57$ & $009.47 \pm 1.54$ & $010.08 \pm 1.55$ \\
\hline & $\left(10^{3} / \mathrm{mm}^{3}\right)$ & Goat & 10 & $009.00 \pm 1.28$ & $009.92 \pm 1.15$ & $014.76 \pm 0.84$ & $011.50 \pm 1.05$ \\
\hline \multirow[t]{2}{*}{ (10) } & Calcium & Sheep & 10 & $006.16 \pm 0.75$ & $006.07 \pm 0.70$ & $006.28 \pm 0.64$ & $006.21 \pm 0.46$ \\
\hline & ( mg /dl ) & Goat & 10 & $006.13 \pm 0.18$ & $006.14 \pm 0.23$ & $006.15 \pm 1.11$ & $005.91 \pm 0.97$ \\
\hline \multirow[t]{2}{*}{ (11) } & Albumin & Sheep & 10 & $003.25 \pm 0.46$ & $003.11 \pm 0.17$ & $003.19 \pm 0.56$ & $033.51 \pm 0.52$ \\
\hline & ( g / dl ) & Goat & 10 & $003.18 \pm 0.28$ & $003.43 \pm 1.02$ & $003.11 \pm 0.41$ & $003.18 \pm 0.71$ \\
\hline \multirow[t]{2}{*}{ (12). } & TSP ( g / dl ) & Sheep & 10 & $007.66 \pm 0.79$ & $007.71 \pm 1.04$ & $007.75 \pm 1.09$ & $008.43 \pm 0.64$ \\
\hline & & Goat & 10 & $007.89 \pm 0.92$ & $007.47 \pm 0.95$ & $006.97 \pm 2.34$ & $008.26 \pm 0.50$ \\
\hline \multirow[t]{2}{*}{ (13) } & Glucose & Sheep & 10 & $071.37 \pm 19.10$ & $067.80 \pm 11.41$ & $072.21 \pm 12.41$ & $071.96 \pm 9.13$ \\
\hline & $(\mathrm{mg} / \mathrm{dl})$ & Goat & 10 & $072.69 \pm 15.61$ & $069.80 \pm 10.81$ & $066.82 \pm 12.68$ & $071.49 \pm 13.51$ \\
\hline
\end{tabular}

*Significantly difference at $(\mathrm{p}<0.01$ ).

\section{Biochemical studies}

The serum calcium, albumin, total serum protein (TSP) and glucose were determined in sheep and goats at pre-immunization and at $7^{\text {th }}, 14^{\text {th }}$ and $21^{\text {st }}$ day of post-immunization with PPR-VAC $\AA$ and the results are presented in Table 2. No significant difference was observed in any of the investigated biochemical constituents in sheep and goats due to immunization against PPR. But the TSP in both the sheep $(8.43 \pm 0.69 \mathrm{~g} / \mathrm{dl})$ and goats $(8.26 \pm 0.50 \mathrm{~g} / \mathrm{dl})$ at $21^{\text {st }}$ day of post-immunization increased insignificantly ( $\left.>0.05\right)$ in comparison to the pre-immunization values of sheep $(7.66 \pm 0.79 \mathrm{~g} / \mathrm{dl})$ and goats $(7.89 \pm 0.92 \mathrm{~g} / \mathrm{dl})$ which might be due to humoral immune response for the production of immunoglobulin antibodies against inoculated PPR virus antigens.

\section{ACKNOWLEDGEMENTS}

The authors acknowledge the Bangladesh Livestock Research Institute (BLRI), Savar, Dhaka for technical assistance to use C-ELISA to test the sera samples.

\section{REFERENCES}

1. Anderson J and Mackay JA (1994). The detection of antibodies against Peste des Petits Ruminants virus in the cattle, sheep and the goats and the possible implication to rinderpest control programmes. Epidemiology and Infection 112 : 225 $-231$. 
2. Awa DW, Ngagnou A, Tefiang E, Yaya D and Njoya A (2002). Post-vaccination and colostral Peste des Petits Ruminants antibody dynamics in research flocks of Kidri goats and foible sheep of north Cameroon. Preventive Veterinary Medicine $55: 265-271$.

3. Barrett T, Pronab D, Sreenivasa BP and Corteyn M (1997). Recent epidemiology of Peste des Petits Ruminants virus ( PPRV ). Veterinary Microbiology $88: 125-130$.

4. Bidjeh K, Diguimbaya C, Hendrikx P, Debet V, Tchari D and Naissinger S (1999). Maternal immunity in young goats or sheep whose dams were vaccinates with anti-peste des petits ruminants. Cah Agriculture $3: 219-222$.

5. Das KK, Shil NK and Islam MR (2007). Sero-epidemiological investigation on Peste des Petits Ruminants in black Bengal goats. Bangladesh Journal of Microbiology 24 : $143-145$.

6. Gupta SP (1982). Statistical Methods. $19^{\text {th }}$ edn., Sultan Chand and Sons, Publisher, 23 Daryagonj, New Delhi, India.

7. Islam MR, Shamsuddin M, Das PM and Dewan ML (2001). An outbreak of Peste des Petits Ruminants ( PPR ) in Black Bengal goats in Mymensingh, Bangladesh. The Bangladesh Veterinarian $18: 14-19$.

8. Islam MR, Giasuddin M, Rahman MM and Kafi MA (2003). Antibiotic combined hyperimmune serum therapy (ACHST ) for Peste des Petits Ruminants ( PPR ) infected goats. Bangladesh Journal of Veterinary Medicine 1: 49 - 51.

9. Khan MR, Haider MG, Alam KJ, Hossain MG, Chowdhury SMZH and Hossain MM (2005). Pathological investigation of Peste des Petits Ruminants ( PPR ) in goats. Bangladesh Journal of Veterinary Medicine $3: 134$ - 138.

10. Razzaque MA, Rahman MB, Kafi MA, Islam MR, Khan MFR and Nazir KAMNH (2004). Application of C-ELISA for detection of PPRV-specific antibodies in domestic ruminants in different areas of Mymensingh, Bangladesh. Molecular Biology and Biotechnology Journal $2: 40$ - 43.

11. Samad MA (2001). Pashu Palon O Chikitsavidya. $2^{\text {nd }}$ edn, LEP No. 09, BAU Campus, Mymensingh, Bangladesh.

12. Samad MA (2008). Animal Husbandry and Veterinary Science. Volume 2, ${ }^{\text {st }}$ Pub., LEP No. 12, BAU Campus, Mymensingh, Bangladesh.

13. Sil BK, Taimur MJFA, Hossain KM, Giasuddin M, Haque ME, Rahman MM, Roy A, Alam J, Islam MR, Rasid B, Akter N, Pramanic BK and Anower AKMM (2001). Development of Mab-based ELISA for the rapid detection and accurate field diagnosis of PPR virus. Bangladesh Journal of Livestock Research 7 : 48 - 63.

14. Taylor WP (1979). Protection of goats against Peste des Petits Ruminants with attenuated Rinderpest virus. Research in Veterinary Science $27: 321-324$. 